\title{
PROBLEMATIKA DAN STRATEGI PENINGKATAN MUTU PENDIDIKAN TINGGI DI INDONESIA
}

Oleh: Asep Saepudin*

\section{Abstrak}

Problematikan dan peningkatan kualitas mutu bagi perguruan tinggi merupakan dua hal penting yang perlu diperhatikan. Kenyatan menunjukan bahwa selama ini perguruan tinggi tidak terlepas dari persoalan (problematika) yang berkenaan dengan tiga hal, yaitu: (1) masih rendahnya pemerataan dalam memperoleh pendidikan, (2) masih rendahnya kualitas dan relevansi pendidikan, dan (3) masih lemahnya manajemen pendidikan. Kondisi tersebut perlu segera diselesaikan melalui reformasi pendidikan yang mengarah kepada peningkatan kualitas mutu dengan pendekatan konsep manajemen mutu terpadu atau Total Quality Manajement (TQM). Walupun konsep tersebut pada mulanya dikembangkan dalam dunia bisnis dan industri, namun dapat diterapkan pula pada bidang pendidikan, khususnya di perguruan tinggi.

Kendatipun demikian, berbeda dengan manajemen bisnis atau industri, penerapan Total Quality Manajement (TQM) dalam mencapai manajemen kualitas mutu di Perguruan Tinggi (management for quality in higer education institutions) lebih difokuskan pada pada dua hal, yaitu: Pertama, stimulasi dari koherensi proses belajar. Kedua, Analisis kebutuhan berbagai kelompok peserta didik. yakni mahasiswa sebagai peserta didik. Oleh karenanya orientasi terhadap peserta didik adalah kunci management for quality in higer education institutions.

*) Drs. Asep Saepudin, M.Pd., adalah Kandidat Doktor Universitas Pendidikan Indonesia. 


\section{PENDAHULUAN}

Konsep mutu atau manajemen mutu pada mulanya dikembangkan dalam dunia bisnis, sebagai takaran untuk menjaga keseimbangan dan kesetabilan organisasinya dalam menyeimbangkan persaingan usaha mereka yang semakin tajam. Namun kemudian, dalam perkembangan berikutnya konsep mutu diterapkan pula pada bidang lain seperti industri, pemertintahan termasuk bidang pendidikan. Pengertian mutu itu sendiri dikemukakan oleh banyak pakar sesuai sundut pandangnya masingmasing. Walaupun terminilogi tentang mutu sangat bervariasi namun memiliki makna yang sama yaitu mutu dalam arti quality. Tjutju Yuniarsih (2003:2) mengutif ungkapan beberapa ahli seperti: Phipip B. Crosby (1979) misalnya, yang berpendapat bahwa mutu berarti kesesuaian terhadap persyaratan. Sedangkan K. Ishikawa (1985) dan Josep M. Juran (1989) masing-masing mendefinisikan mutu sebagai kepuasan pelanggan dan mutu sebagai kesesuaian dengan pengguna.

Pengertian mutu yang lebih formulatif dikemukakan Eduardo Morato (1993) bahwa: Quality is this function of people expressing themselves in the fullest way possible". Senada dengan itu, Scott Parry (1995) berpendapat bahwa: " Quality is the integral value that accrues in product or service as each employee contributes to it. And value must come from empowered employees-people who have been released from their centuries old". Kedua pendapat di atas mengandung makna bahwa mutu produk merupakan hasil perpaduan usaha dari semua komponen dan dijadikan sebagai salah satu alat ukur keberhasilan produsen, dengan melihat tingkat kepuasan customers dan stakeholders, baik internal maupun eksternal.

Sama halnya dengan konsep di atas, takaran mutu bagi perguruan tinggi pun tentu harus diukur dari dua hal, pertama: tingkat kepuasan mahasiswa, lulusan, serta masyarakat pengguna jasa pendidikan lainnya sebagai customers. Kedua, harus dilihat dari sudut pandang tugas dan tanggung jawab perguruan tinggi dan badan penyelenggara perguruan tinggi tersebut (yang dalam dunia bisnis disitilahkan stakeholders), dalam pengertian bahwa perguruan tinggi harus konsisten 
dalam memelihara mutu keseimbangan fungsi instrumental dan fungsi instrinsiknya. Fungsi instrumental mencerminkan kehendak mengedepankan antara nilai-nilai lulusan perguruan tinggi dengan kualifikasi kebutuhan pembangunan, sedangkan fungsi instrinsik memuat cita-cita membentuk pribadi-pribadi yang menghayati nilai-nilai universal. Integrasi kedua fungsi perguruan tinggi yang dimaksud dapat bermuara kepada ikhtiar memuliakan potensi manusia dan nilai-nilai kemanusiaan.

\section{POTRET PROBLEMATIKA PENDIDIKAN TINGGI INDONESIA}

Tidak dipungkiri, sampai saat ini banyak prestasi yang diraih pendidikan tinggi Indonesia baik dalam skala nasional, regional maupun internasional. Namun juga kita tidak dapat menutup mata, ternyata masih banyak permasalahan pendidikan yang perlu segera dibenahi secara serius. Tulisan ini akan lebih banyak menyoroti permasalahan dan kelemahan pendidikan tinggi di Indoensia daripada prestasi yang diraihnya, dengan asumsi perubahan untuk lebih baik harus dimulai dengan mengkritisi kelemahan atau persoalan yang ada selama ini. Permasalah (problematika) umum pendidikan di Indonesia yang selalu muncul kepermukaan adalah berkenaan dengan tiga hal, yaitu: (1) masih rendahnya pemerataan dalam memperoleh pendidikan, (2) masih lemahnya manajemen pendidikan, dan (3) masih rendahnya kualitas dan relevansi pendidikan. (propenas 2000-2004).

Tanpa berniat mengenyampingkan persoalan pendidikan dasar dan menengah, sesuai tema di atas, uraian berikut mencoba menampilkan ketiga indikator di atas dalam tataran pendidikan tinggi. Indikator pertama, tingkat pemerataan pendidikan, kaitannya dengan angka partisipasi masyarakat dalam melanjutkan studi di perguruan tinggi belum sesuai harapan. Berdasarkan studi MD Dahlan (2000), pada tahun 1995 saja, jumlah mahasiswa seluruh Indonesia sebanyak 2.200.000 orang, sedangkan jumlah penduduk kelompok usia 19-24 tahun (yang seyogianya belajar di PT) sebanyak 22.780 .000 orang. Ini berarti sekitar \pm 20 juta pemuda tidak mengeyam pendidikan tinggi. 
Dari jumlah 2.2 juta mahasiswa yang belajar di perguruan tinggi tersebut, tersebar di PTN sebanyak 500.000, di PTA dan PT Dinas, sebanyak 330.000, dan di PTS sebanyak 1.365.000. Dengan komposisi pilihan program studi eksakta sekitar $\pm 19 \%$, teknik (Engineering) $\pm 14 \%$, dan program studi social \& Humaniora $\pm 67 \%$. (Bun Yamin Ramto, 2000).

Pada perkembangan tahun-tahun berikutnya terdapat peningkatan jumlah angka partisipasi melanjutkan studi pada jenjang pendidikan tinggi. Tahun 1997/1998 jumlah mahasiswa sebanyak 2.382.802 orang yang tersebar di PTN sebanyak 874.972 orang, dan di PTS sebanyak 1.507.830 orang. Selanjutnya pada tahun 1998/1999 dan 1999/2000, jumlah mahasiswa di PTN meningkat positif, sedangkan pada PTS peningkatnnya relatif konstan. Data tersebut dapat dilihat pada tabel berikut:

Tabel 1:

Jumlah Siswa/Mahasiswa Sekolah/PT Negeri dan Swasta dari 1997/1998 s.d. 1999/2000

\begin{tabular}{|c|r|r|r|r|r|r|r|r|r|}
\hline \multirow{2}{*}{$\begin{array}{l}\text { Jenjang } \\
\text { Sekolah }\end{array}$} & \multicolumn{3}{|c|}{$1997 / 1998$} & \multicolumn{3}{c|}{$1998 / 1999$} & \multicolumn{2}{|c|}{$1999 / 2000$} \\
\cline { 2 - 11 } & Negeri & Swasta & $\begin{array}{c}\% \\
\text { Swasta }\end{array}$ & Negeri & Swasta & $\begin{array}{c}\% \\
\text { Swasta }\end{array}$ & Negeri & \multicolumn{1}{l}{ Swasta } & $\begin{array}{c}\% \\
\text { Swasta }\end{array}$ \\
\hline TK & 12.192 & 1.675 .273 & 99,28 & 14.934 & 1569.950 & 99,06 & 16.745 & 1.596 .016 & 98,96 \\
\hline SD & $23 . .804 . .633$ & $1.862 . .945$ & 7,26 & $23 . .841 .741$ & 1.846 .152 & 7,19 & 23.757 .585 & 1.857 .251 & 7,25 \\
\hline SLTP & 5.163 .628 & 2.432 .758 & 32,03 & 5.258 .460 & 2.306 .168 & 30,49 & 5.392 .172 & 2.207 .921 & 29,05 \\
\hline SM & 2.109 .834 & 2.428 .216 & 53,51 & 2.219 .254 & 2.469 .321 & 52,67 & 2.267 .391 & 2.511 .534 & 52,55 \\
\hline PT & $\mathbf{8 7 4 . 9 7 2}$ & $\mathbf{1 . 5 0 7 . 8 3 0}$ & $\mathbf{9 3 , 2 8}$ & $\mathbf{1 . 1 7 1 . 5 1 1}$ & $\mathbf{1 . 5 2 6 . 4 6 4}$ & $\mathbf{5 6 , 5 8}$ & $\mathbf{1 . 4 6 7 . 8 6 7}$ & $\mathbf{1 . 6 5 8 . 4 4 0}$ & $\mathbf{5 3 , 0 5}$ \\
\hline
\end{tabular}

Sumber: Pusat Statistik Pendidikan, Balitbang Depdiknas, 2001 (Safrudin Chamidi:2004)

Data di atas, menunjukan bahwa setiap tahunnya, terdapat peningkatan jumlah mahasiswa baik di PTN maupun di PTS. Namun demikian kondisi tersebut belum menunjukan angka yang signifikan bila dibandingkan dengan pertumbuhan jumlah penduduk kelompok usia 19-24 tahun yang seyogianya belajar di perguruan tinggi.

Berkaitan dengan angka partisipasi mahasiswa, dalam skala regional perguruan tinggi di Indonesia pada umumnya masih termasuk papan bawah. hal ini dapat dilihat dari jumlah angka partisipasi mahasiswa perguruan tinggi di masing-masing negara dimaksud. Sebagai 
komparasi, angka partisipasi mahasiswa untuk negara-negara tetangga terdekat (ASEAN) seperti Filipina sudah mencapai $\pm 30 \%$, Thailand \pm $28 \%$, Malaysia $\pm 18 \%$, sedangkan Indoensia baru $\pm 11 \%$. Apalagi jika dibandingkan dengan Korea Selatan yang sudah mencapai angka partisipasi $\pm 38 \%$, sedangkan Jepang $\pm 53 \%$. (Bun Yamin Ramto, 2000). Rendahnya angka partisipasi masyarakat pada pendidikan tinggi baik dalam sekala nasional maupu regional sebagaimana diuraikan di atas, berdasakan penyataan umum disebabkan oleh banyak faktor. Salah satu faktor yang paling dominan adalah faktor keterbatasan kemampuan ekonomi masyarakat, daripada keterbatasan jumlah perguruan tinggi baik daya tampung maupun variasi program studinya. Pernyataan di atas cukup beralasan, sebab jumlah perguruan tinggi di Indonesia baik perguruan tinggi negeri (PTN), perguruan tinggi swasta (PTS), maupun perguruan tinggi kedinasan (PTK) termasuk perguruan tinggi Agama Islam Negeri (PTAIN) dan perguruan tinggi Agama Islam Swasta (PTAIS) relatif banyak bahkan setiap tahunnya ada kecederungan bertambah. Pada tahun 1997 saja jumlah PTN sebanyak 77 buah, sedangkan PTS berjumlah 1365 atau sekitar $94.66 \%$ kemudian meningkat mencapai jumlah 1557 (95.35\%) pada tahun 2000, yang diperkirakan tahun 2004 lebih dari itu dan angka tersebut akan terus meningkat pada tahuntahun yang akan datang. Data tersebut dapat dilihat pada tabel berikut:

Tabel 2:

Jumlah Sekolah/PT Negeri dan Swasta dari 1997/1998 s.d. 1999/2000

\begin{tabular}{|c|r|r|r|r|r|r|r|r|r|}
\hline & \multicolumn{3}{|c|}{$1997 / 1998$} & \multicolumn{2}{|c|}{$1998 / 1999$} & \multicolumn{2}{|c|}{$1999 / 2000$} \\
\hline $\begin{array}{c}\text { Jenjang } \\
\text { Sekolah }\end{array}$ & Negeri & Swasta & $\begin{array}{c}\text { \% } \\
\text { Swasta }\end{array}$ & Negeri & Swasta & $\begin{array}{c}\text { \% } \\
\text { Swasta }\end{array}$ & Negeri & Swasta & $\begin{array}{c}\text { \% } \\
\text { Swasta }\end{array}$ \\
\hline TK & 168 & 40.395 & 99,59 & 212 & 40.669 & 99,48 & 225 & 41.092 & 99,46 \\
\hline SD & 140.661 & 10.260 & 6,80 & 140.770 & 10.272 & 60,80 & 140.316 & 10.296 & 6,84 \\
\hline SLTP & 9.841 & 10.936 & 52,64 & 10.374 & 10.586 & 50,51 & 10.495 & 10.371 & 49,70 \\
\hline SMU & 3.481 & 8.630 & 71,26 & 3.556 & 8.453 & 70,39 & 3.611 & 8.458 & 70,08 \\
\hline PT & $\mathbf{7 7}$ & $\mathbf{1 . 3 6 5}$ & $\mathbf{9 4 , 6 6}$ & $\mathbf{7 7}$ & $\mathbf{1 . 4 4 9}$ & $\mathbf{9 4 , 9 5}$ & $\mathbf{7 6}$ & $\mathbf{1 . 5 5 7}$ & $\mathbf{9 5 , 3 5}$ \\
\hline
\end{tabular}

Sumber: Pusat Statistik Pendidikan, Balitbang Depdiknas, 200(Safrudin Chamidi:2004)

Berdasarkan data di atas, tampak komposisi jumlah perguruan negeri relatif lebih rendah bila dibandingkan dengan komposisi jumlah

72 Asep Saefudin: Problematika \& Strategi Peningkatan 
perguruan tinggi swasta. Sehingga dengan kasat mata akan disimpulkan begitu besar jumlah mahasiswa di perguruan tinggi swasta. Padahal sesungguhnya jumlah perguruan tinggi tersebut tidak linier dengan jumlah mahasiswanya. Walaupun angka jumlah perguruan tinggi negeri kecil, namun angka rata-rata jumlah mahasiswa di perguruan tinggi negeri adalah \pm 12.000 mahasiswa per perguruan tinggi, sedangkan untuk perguruan tinggi swasta hanya \pm 1.200 mahasiswa per perguruan tinggi. Dengan demikian jumlah mahasiswa yang ada di perguruan tinggi negeri juga cukup besar, telebih-lebih dengan dibukanya kelas ekstention, diploma, polyteknik atau kampus 2 di perguruan tinggi negeri, yang setiap angkatannya menerima ribuan jumlah mahasiswa, menyedot calon mahasiswa yang seharusnya menjadi jatah bagi perguruan tinggi swasta.

Kumulatif jumlah mahasiswa pada kedua jenis perguruan tinggi di atas, tidak berarti terbatasnya peluang dan kesempatan untuk melanjutkan studi di pergruan tinggi. Kenyataan menunjukan masih banyak perguruan tinggi (terutama swata) yang masih kekurangan mahasiswa pada setiap awal tahun ajarannya.

Data lain yang berkenaan dengan jumlah perguruan tinggi di Indonesia adalah perguruan tinggi yang dibina oleh Departemen Agama. Saat ini Departemen Agama membuka Perguruan Tinggi Agama Islam (PTAI), yang terbagi atas Perguruan Tinggi Agama Islam Negeri (PTAIN), maupun Perguruan Tinggi Agama Islam Swasta (PTAIS), dengan jumlah yang cukup besar sebagaimana tabel berikut:

Tabel 3:

Jumlah Madrasah/PTAI Negeri dan Swasta dari 1997/1998 s/d 1999/2000

\begin{tabular}{|c|r|r|r|r|r|r|r|r|r|}
\hline $\begin{array}{c}\text { Jenjang } \\
\text { Madrasah }\end{array}$ & \multicolumn{3}{|c|}{$1997 / 1998$} & \multicolumn{3}{|c|}{$1998 / 1999$} & \multicolumn{2}{|c|}{$1999 / 2000$} \\
\cline { 2 - 11 } & Negeri & Swasta & $\begin{array}{c}\text { \% } \\
\text { Swasta }\end{array}$ & Negeri & Swasta & $\begin{array}{c}\text { \% } \\
\text { Swasta }\end{array}$ & Negeri & Swasta & $\begin{array}{c}\% \\
\text { Swasta }\end{array}$ \\
\hline RA/BA & 0 & 11.566 & 100,00 & 0 & 11.566 & 100,00 & 0 & 11.566 & 100,00 \\
\hline MI & 1.075 & 23.437 & 95,61 & 1426 & 23.171 & 94,20 & 1.454 & 20.000 & 93,22 \\
\hline MTs & 1.141 & 8.649 & 88,35 & 1.131 & 8639 & 88,43 & 1.1781 & 8.682 & 88,05 \\
\hline MA & 558 & 2.977 & 84,21 & 597 & 3.027 & 83,53 & 601 & 3.001 & 83,31 \\
\hline PTAI & $\mathbf{4 7}$ & $\mathbf{2 5 1}$ & $\mathbf{8 4 , 2 3}$ & $\mathbf{4 7}$ & $\mathbf{2 5 1}$ & $\mathbf{8 4 , 2 3}$ & $\mathbf{4 7}$ & $\mathbf{2 5 1}$ & $\mathbf{8 4 , 2 3}$ \\
\hline
\end{tabular}

Sumber: Pusat Statistik Pendidikan, Balitbang Depdiknas, 2001 (Safrudin Chamidi:2004) 
Menurut tabel 3 di atas, nampak bahwa pada lembaga Pendidikan Tinggi Agama Islam (PTAI) terdapat kecenderungan yang berbeda dengan kecenderungan yang ada di lembaga perguruan tinggi umum PTN dan PTS, dimana jumlah lembaga PTAI baik untuk PTAIN maupun PTAIS tidak mengalami perubahan jumlah dari 1997/1998 ke 1999/2000. Namun demikian, jumlah PTAI tersebut telah berkontribusi dalam memberikan peluang dan kesempatan belajar khususnya bagi mereka lulusan dengan latar belakang pendidikan Islam seperti halnya Madrasah Aliyah (MA), maupun bagi siapapun yang memiliki minat dan bakat mempelajari disiplin ilmu agama.

Banyaknya institusi pendidikan tinggi dan besarnya kesempatan untuk melanjutkan studi di pergruan tinggi, akan semakin nampak ketika kita melihat data jumlah perguruan tinggi kedinasan (PTK) yang dalam tulisan ini tidak dapat ditampilkan. Oleh karena itu, saat ini sesungguhnya tidak ada alasan bagi anak bangsa untuk tidak dapat menikmati studi di perguruan tinggi pada alam kemerdekaan ini. Namun demikian, kenyataannya sangat ironis dimana angka partisipasi melanjutkan studi di perguran tinggi untuk penduduk kelompok usia 19-24 tahun relatif rendah, bila dibandingkan dengan banyaknya jumlah perguruan tinggi yang tersebar ditiap wilayah di pelosok negeri ini.

Untuk sementara dapat disimpulkan bahwa persoalan mendasar rendahnya pemerataan dan angka partisipasi melanjutkan studi ke perguruan tinggi bukan kurangnya jumlah institusi perguruan tinggi, namun disebabakan oleh banyak factor lain, yang salah satunya adalah faktor ketidakmampuan ekonomi masyarakat sehubungan dengan mahalnya biaya studi di perguruan tinggi yang setiap tahunnya terus melonjak. Bagi masyarakat yang memiliki kemampuan finansial (the have), mahalnya biaya pendidikan nampaknya bukan masalah krusial selama anaknya mau dan mampu untuk melanjutkan studi. Tetapi bagi sebagian besar masyarakat yang kemampuan ekonominya rendah atau penghasilannya relatif kecil, sementara memiliki jumlah anak yang harus disekolahkan lebih dari satu, tentu mahalnya biaya pendidikan merupakan problem yang sulit dipecahkan. Oleh karena itu, perlu kebijakan 
pemerintah dan keberpihakan dunia usaha serta bantuan pimpinan perguruan tinggi bagi masyarakat ekonomi lemah kaitannya dalam memfasilitasi mereka yang berusia 19-24 tahun untuk dapat melanjutkan studi di perguruan tinggi dalam rangka pemerataan pendidikan dan peningkatan tingkat partisipasi pendidikan di perguruan tinggi.

Upaya untuk meningkatkan angka partisipasi mahasiswa sebagaimana disebutkan diatas, perlu diperhatikan dan diupayakan. Terlebih-lebih dengan Informasi yang disampaikan Bun Yamin Ramto (2004:7) tentang rencana pemerataan dan angka partisipasi studi di perguruan tinggi, bahwa rencana pertumbuhan dan pengembangan perguruan tinggi di Indonesia secara makro dan kuantitatif adalah bahwa pada tahun 2019, angka partisipasi mahasiswa diharapkan sudah mencapai $25 \%$ dari jumlah penduduk yang berusia 19-24 tahun, yang pada waktu itu diperkirakan kurang lebih 25 juta jiwa. Jadi jumlah mahasiswa Indoensia pada waktu awal memasuki milenium ke 3 ini (2020) direncanakan kurang lebih 6 juta orang. Dari jumlah mahasiswa itu nanti direncanakan yang akan dikelola oleh perguruan tinggi negeri hanya $\pm 1,1$ juta mahasiswa, sedangkan \pm 4,9 juta mahasiswa akan dikelola oleh pihak swasta. Ini berarti bahwa daya tampung perguruan tinggi negeri akan bertambah dua kali dari yang ada sekarang, sedangkan untuk perguruan tinggi swasta akan menjadi tiga kali dari yang ada sekarang.

Indikator kedua, kaitannya dengan sistem dan manajemen pendidikan di Indonesia, dalam studi yang dilakukan Tampubolon (2001) dijelaskan bahwa sistem dan manajemen pendidikan di Indonesia masih rendah akibat sering gonta gantinya sistem pendidikan. Sudah menjadi tradisi di negeri ini, ketika terjadi pergantian menteri pendidikan nasional sebagai konsekuensi bergantinya susunan kabinet, maka akan terjadi pula pergantian kebijakan pendidikan nasional kita. Kondisi tersebut nampaknya baik selama untuk perbaikan pembangunan pendidikan di negeri tercinta ini, namun alangkah lebih baiknya jika kebijakan dari satu kabinet kepada kabinet lain berdasar pada satu bentangan fondasi atau flatform yang saling melanjutkan dan melengkapi sehingga tercipta tahapan penyempurnaan bagi pembaharuan sistem pendidikan di Indonesia untuk jangka panjang. 
Indikator Ketiga, berkenaan dengan kualitas dan relevansi pendidikan di Indonesia, ada baiknya memotret mutu pendidikan nasional, khususnya perguruan tinggi ditinjau dari skala nasional dan regional/ Internasional. Sesungguhnya tidak ada ikatan aturan apa dan apa siapa yang seharusnya menilai mutu pendidikan tinggi, karena sesungguhnya yang harus meinilai kinerja suatu perguruan tinggi adalah masyarakat luas selaku pelaku (customers) atau pengguna (user) jasa pendidikan. Saat ini banyak lembaga independen baik tingkat nasional maupun internasional yang berwenang memberikan sertifiaksi tentang mutu suatu penyelenggaraan pendidikan tinggi, dan tidak sedikit perguruan tinggi di Indonesia yang memiliki kualifikasi baik diakreditasi oleh lembaga internasioanl tersebut misalnya dengan mendapat sertifikasi ISO atau berpartner dengan lembaga lisensi tarap internasional lainnya seperti dengan Mocrosoft.

Umumnya kinerja program studi dan peringkat akreditasi perguruan tinggi di Indonesia diakredit oleh Badan Akreditasi Nasional Perguruan Tinggi (BAN-PT). Badan ini melakukan penilian terhadap perguruan tinggi dengan klasifikasi pringkat A (baik sekali), B (Baik), C (Cukup) dan $\mathbf{D}$ (Tidak terakreditasi). Sebagai informasi, jumlah dan peringkat akreditasi program studi perguruan tinggi di Indonesia pada setiap jenjangnya dapat dilihat dapat dilihat dari table berikut:

Tabel 4:

Jumlah Program Studi Jenjang Diploma III menurut Perguruan Tinggi Penyelenggara dan Peringkat Akreditasi

\begin{tabular}{|c|c|c|c|c|c|}
\hline \multirow{2}{*}{$\begin{array}{c}\text { Perguruan } \\
\text { Tinggi } \\
\end{array}$} & \multicolumn{4}{|c|}{ Peringkat } & \multirow[t]{2}{*}{ Jumlah } \\
\hline & $\mathbf{A}$ & B & $\mathrm{C}$ & D & \\
\hline PTN & 11 & 40 & 26 & 3 & 80 \\
\hline PTS & 41 & 180 & 204 & 11 & 436 \\
\hline PTK & 0 & 7 & 7 & 0 & 14 \\
\hline PTA & 0 & 0 & 0 & 0 & 0 \\
\hline PTAIS & 0 & 0 & 0 & 0 & 0 \\
\hline Total & 52 & 227 & 237 & 14 & 530 \\
\hline
\end{tabular}

Sumber: Buku Direktori Akreditasi BAN-PT 2003 
Tabel 5:

Jumlah Program Studi Jenjang Sarjana menurut Perguruan Tinggi Penyelenggara dan Peringkat Akreditasi

\begin{tabular}{|c|c|c|c|c|c|}
\hline \multirow{2}{*}{$\begin{array}{c}\text { Perguruan } \\
\text { Tinggi }\end{array}$} & \multicolumn{4}{|c|}{ Peringkat } & \multirow[t]{2}{*}{ Jumlah } \\
\hline & $\mathbf{A}$ & B & $\mathrm{C}$ & D & \\
\hline PTN & 268 & 665 & 328 & 23 & 1274 \\
\hline PTS & 225 & 1448 & 1336 & 153 & 3162 \\
\hline PTK & 3 & 16 & 10 & 1 & 30 \\
\hline PTA & 5 & 99 & 92 & 24 & 220 \\
\hline PTAIS & 40 & 142 & 72 & 19 & 273 \\
\hline Total & 541 & 2360 & 1838 & 220 & 4959 \\
\hline
\end{tabular}

Sumber: Buku Direktori Akreditasi BAN-PT 2003

Tabel 6:

Jumlah Program Studi Jenjang Magister menurut Perguruan Tinggi Penyelenggara dan Peringkat Akreditasi

\begin{tabular}{|c|c|c|c|c|c|}
\hline \multirow{2}{*}{$\begin{array}{c}\text { Perguruan } \\
\text { Tinggi }\end{array}$} & \multicolumn{4}{|c|}{ Peringkat } & \multirow[t]{2}{*}{ Jumlah } \\
\hline & $\mathbf{U} / \mathbf{A}$ & $-/ \mathbf{B}$ & $\mathrm{B} / \mathrm{C}$ & T/D & \\
\hline PTN & 221 & 5 & 63 & 0 & 289 \\
\hline PTS & 47 & 5 & 43 & 3 & 98 \\
\hline PTK & 0 & 0 & 0 & 0 & 0 \\
\hline PTA & 0 & 0 & 0 & 0 & 9 \\
\hline PTAIS & 0 & 0 & 0 & 0 & 0 \\
\hline Total & 268 & 10 & 106 & 3 & 396 \\
\hline
\end{tabular}

Sumber: Buku Direktori Akreditasi BAN-PT 2003

Tabel 7:

Jumlah Program Studi Jenjang Doktor menurut Perguruan Tinggi Penyelenggara dan Peringkat Akreditasi

\begin{tabular}{|c|c|c|c|c|c|}
\hline \multirow{2}{*}{$\begin{array}{c}\text { Perguruan } \\
\text { Tinggi }\end{array}$} & \multicolumn{4}{|c|}{ Peringkat } & \multirow[t]{2}{*}{ Jumlah } \\
\hline & $\mathbf{A}$ & B & C & D & \\
\hline PTN & 15 & 16 & 4 & 0 & 35 \\
\hline PTS & 0 & 0 & 0 & 0 & 0 \\
\hline PTK & 0 & 0 & 0 & 0 & 0 \\
\hline PTA & 0 & 0 & 0 & 0 & 0 \\
\hline PTAIS & 0 & 0 & 0 & 0 & 0 \\
\hline Total & 15 & 16 & 4 & 0 & 35 \\
\hline
\end{tabular}

Sumber: Buku Direktori Akreditasi BAN-PT 2003 
Berdasarkan ketiga tabel diatas, rata-rata klasifikasi peringkat akreditasi perguruan tinggi di Indonesia ada pada rentang B an C. Hal ini menunjukan bahwa kinerja program studi di masing-masing perguruan tinggi harus terus didorong untuk terus meningkatkan kualitas dirinya sehingga mencapai angka mutu A sebagaimana yang diharapkan.

Selanjutnya dalam skala Internasional, pendidikan tinggi di Indonesia masih sangat ketinggalan baik kuantitas maupun kualitasnya. Dalam skala ini, Indonesia adalah salah satu negara yang dalam percaturan dunia reputasi pendidikannya masih tertinggal dan harus bekerja keras membenahi sistem pendidikannya. Sebagai bukti ketertinggalan, Asiaweek mislanya, yang melakukan survey pada tahun 2000 terhadap perguruan tinggi di Asia dan Australia yang dibedakan berdasarkan jenis lembaga, yaitu: universitas, institut teknologi, program MBA, dan program Diploma. Melaporkan bahwa ternyata universitas yang dianggap terbaik di Indonesia, peringkatnya masih belum begitu menggembirakan dibandingkan dengan universitas di sejumlah negara lain. Empat perguruan tinggi negeri favorit Indonesia (UI, UGM, UNDIP \& Airlangga) yang disurvey masih berada dikelompok peringkat terbawah (dibawah peringkat 60). Sedangkan untuk perguruan tinggi teknik, ITB berada pada peringkat 21 dari 39 negara, yang tahun sebelumnya 1999 ada pada peringkat 15 dari 35 perguruan tinggi yang disurvey.

Kondisi tersebut di atas, merupakan tolok ukur bahwa beberapa lembaga perguruan tinggi yang selama ini difavoritkan di negeri ini, ternyata masih menempati rangking yang kurang membanggakan. Pertanyaan yang muncul kemudian bagaimana dengan perguruan tinggi yang biasabiasa saja termasuk perguruan tinggi swasta di Indonesia yang bertebaran dengan berbagai problematikanya masing-masing.

Masih dalam skala internasional, kualitas lulusan pendidikan tinggi Indonesia dalam hal memenuhi tuntutan perkembangan lapangan kerja kalau dibandingkan dengan pendidikan tinggi di ligkungan ASEAN, ASIA FCIFIC dan DUNIA, juga belum dapat disaingkan. Hal ini tercermin dari banyaknya kesempatan kerja yang ada di Indonesia yang justru diambil oleh tenaga-tenaga asing, terutama untuk tingkat menengah 
ke atas seperti tenaga profesional dan konsultan yang mencapai 50 ribu orang atau setara dengan total pendapatan 2,5 miliar rupiah per tahun (Joetata Hadihardaja, 2002), sementara ribuan sarjana baru diwisuda yang akan memperpanjang antrian pencarai kerja. Padahal saat ini pasca krisis moneter, angka pengangguran intelektual mencapai $(22, \%)$, melampaui angka pengangguran pada umumnya $(7,24 \%)$. Implikasi dari ketidaksiapan bersaing tersebut, akhirnya banyak tenaga kerja Indonesia memilih pekerjaan level bawah.

Rendahnya mutu lulusan pendidikan tinggi Indonesia, terungkap juga dalam hasil penelitian yang dilakukan Wahyu dan Suganda (1999) terhadap mahasiswa tingkat akhir di perguruan tinggi negeri, yang menunjukan bahwa hanya $36 \%$ alumni yang menyatakan dirinya siap pakai, sebagian besar yakni $50 \%$ tidak siap pakai dan sisanya $15 \%$ abstain. Hasil survey ini merupakan salah satu indikator tentang rendahnya kualitas mutu lulusan pendidikan di Indonesia untuk bersaing memasuki dunia kerja. Sinyalemen tersebut mengindikasikan bahwa para lulusan lembaga pendidikan yang akan terjun pada berbagai bidang kualitasnya masih belum memadai untuk langsung mengemban tugas yang diberikan. Sehingga wajar jika kualitas lulusan perguruan tinggi ada dalam kondisi terpuruk jika disandingkan dengan standar kualitas lulusan skala internasional.

Pada aspek lain, yakni tingkat partisipasi global tenaga kerja Indonesia. Fakta di lapangan menunjukan bahwa, partisifasi global mengiriman tenaga kerja lulusan pendidikan Indonesia, saat ini baru mampu mengekspor jasa tenaga kerja yang kurang terampil (seperti TKW) yang semakin langka ditemukan di negara maju. Bila hal tersebut berlanjut terus, maka kita akan menjadi pemegang posisi spesialis penyedia barang dan jasa yang hanya dapat menghasilkan nilai tambah yang rendah. Sementara negara yang dalam posisi semi-industri (Singapura, Taiwan, Korsel, dan Malaysia) menghadapi era globalisasi ekonomi dan pendidikan, sudah melakukan antisipasi jauh sebelumnya dan telah melakukan reformasi pola pikir dan diaktualisasikan melalui konsep yang jelas tentang visi pengembangan SDM dalam memasuki abad 21 melalui institusi pendidikan tingginya. Situasi lingkungan 
strategic pendidikan Indonesia secara nasional ini akan menjadi lebih kedodoran lagi ketika harus bersaing dengan Perguruan Tinggi Asing (PTA) yang sudah diizinkan masuk dan ikut beroperasi di Indonesia, sementara kita belum siap menghadapi persaingan tersebut.

Gambaran tentang rendahnya sistem pendidikan tinggi di Indonesia sebagaimana diuraikan di atas, mengisyaratkan bahwa dalam skala makro nasional terdapat kelemahan-kelemahan kebijakan dan manajemen serta proses pendidikan, yang kemudian menghasilkan produk pendidikan yang kurang berkualitas. Rendahnya mutu dan produk pendidikan sebagaimana diuraikan di atas, pada tataran nasional, setidak-tidakanya ada dua faktor yang menyebabkan kegagalan mutu pendidikan dimaksud, yaitu: umum dan khusus. Penyebab umum adalah kegagalan pendidikan berkenaan dengan rendahnya desain kurikulum, gedung tidak memadai, lingkungan kerja tidak menunjang, sistem dan prosedur kerja tidak cocok, pengaturan waktu tidak mencukupi, kurangnya fasilitas, sumber anggaran, dan pengembangan staf tidak memadai. Sedangkan penyebab khusus karena kegagalan tersebut muncul disebabkan prosedur dan peraturan tidak dipatuhi, staf tidak memiki keterampilan, pengetahuan dan sikap kerja sebagaimana mestinya, kurangnya motivasi, kegagalan komunikasi, serta perlengkapan yang tidak memadai.

Dalam skala mikro institusi penyelenggaraan pendidikan tinggi, juga perlu penataan yang serius, terutama berkenaan dengan jasa layanan perguruan tinggi dimaksud. Tampubolon (2001:71) menjelaskan ada 5 (lima) faktor jasa pendidikan perguruan tinggi yang memiliki pengaruh signifikan terhadap mutu pendidikan tinggi. Kelima faktor tersebut, yakni: 1) jasa adminsitrasi (JA), 2) jasa kurikulum (JK), 3) jasa penelitian (JP), 4) jasa pengeabdian pada masyarakat (JPM), 5) jasa ekstrakurikuler (JK). Kelima jasa di atas disebut jasa sepenuhnya, karena itulah yang benar-benar sepenuhnya diproduksi dan disajikan oleh perguruan tinggi.

Sebagai ilustrasi, dengan menggunakan indikator di atas, Maman Ukas, dkk (2003) melakukan penelitian tentang: "Kualitas Jasa Kependidikan pada Perguruan Tinggi pada Jurusan Pendidikan Ekonomi FPIPS 
Universitas Pendidikan Indonesia" dengan responden para alumni dari jurusan tersebut. Dengan menggunakan ukuran akuntabilitas, efisiensi, efektivitas, kemampuan akademik, kepemerhatian, kreativitas, ketanggapan, penampilan, produktivitas, relevansi, situasi M-M, hasil penelitian menunjukan bahwa jasa kepedidikan jurusan ekonomi Universitas Pendidikan Indonesia belum mencerminkan kriteria yang ideal. Pada umumnya para alumni jurusan pendidikan ekonomi melihat jasa kependidikan berada pada kriteria baik sedang dan jelek. Berdasarkan data penelitian dijelaskan hnaya sekitar $7 \%$ mempersepsikan pada kriteria sangat baik, 35\% baik, 32\% sedang, $21 \%$ kelak, dan sekitar $5 \%$ menyatakan sangat jelak. Data tersebut belum menunjukan bahwa jasa layanan kependidikan di perguruan tinggi dimaksud pada posisi sangat baik. Tentu saja kondisi ini akan berpengaruh terhadap rendahnya mutu pendidikan atau dalam bahasa lain terdapat korelasi positif antara jasa layanan pendidikan yang belum baik dengan rengahnya mutu pendidikan.

Upaya mengatasi kendala atas rendahnya mutu pendidikan, harus dilandasi oleh perubahan sikap dan cara bekerja semua personil. Pimpinan harus memotivasi stafnya agar bekerja lebih baik, misalnya dengan jalan menciptakan iklim kerja yang menyenangkan, menyediakan sarana yang memadai (baik secara kualitas maupun kuantitasnya), menetapkan sistem dan prosedur kerja yang sederhana (dalam arti tidak berbelit-belit), serta memberi penghargaan atas keberhasilan dan prestasi staf. Hal ini memang bukan pekerjaan mudah karena menuntut kerja keras, disiplin tinggi dan pengorbanan semua fihak, terutama dengan merubah mindset dan paradigma kerja yang semula lebih berorientasi pada segi kuantitas dalam pelaksanaan tugas menjadi lebih berorientasi pada mutu pelaksanaan tugas. Dengan demikian kebutuhan akan kehadiran pimpinan dan staf yang profesional menjadi sedemikian penting, karena dari merekalah diharapkan tercapainya output dan outcame yang betul-betul memiliki competitive.

Terlepas dari berbagai upaya di atas, ada baiknya persoalan (prolematika) pendidikan tinggi yang berkembang saat ini perlu segera ditangani melalui reformasi pendidikan dengan menggunakan pendeketan konsep 
manajemen mutu terpadu atau Toatal Quality Management (TQM). Walupun konsep tersebut lebih banyak digunakan dalam dunia bisnis dan industri, namun dalam penerapannya dapat juga digunakan untuk membenahi mutu penyelenggaraan pendidikan tinggi yang ada di Indonesia.

\section{MANAJEMEN MUTU TERPADU (TQM) DALAM PENYELENGGARAAN PENDIDIKAN TINGGI}

Istilah Total Quality Management (TQM) atau Manajemen Kualitas Terpadu sering dihubungkan dengan istilah lain seperti QCP (Quality Control Program), QIP (Quality Improvement Program), atau CQI (Continous Quality Improvement). Istilah-istilah tersebut diatas, walaupun memiliki prisip yang relatif berbeda, namun saling keterkaitan dan merujuk pada maksud yang sama yaitu meningkatan kualitas (mutu). Akhir-akhir ini, istilah TQM lebih populer digunakan dan diwacanakan oleh para ahli dari berbagai kalangan dan media masa.

Manajemen Kualitas Terpadu (TQM) sering diartikan Quality improvement yang oleh Elaine Biech (1994) diartikan: a customerfocused, quality-centered, fact-based, team-driven, senior-managementled process to achieve an organization"s startegic imperative through continu process improvement.

Pengertian lain yang lebih formulatif (Azrul Azwar, 1995) diuraikan bahwa manajemen kualitas terpadu (TQM) sebuah proses bimbingan manajemen untuk meningkatkan kualitas layanan strategis yang dilakukan dan dikembangkan secara terpadu dan berkesinambungan. Karena sebuah proses, maka mutu layanan harus dipadukan dengan manajemen program secara keseluruhan.

Terlepas dari definisi di atas, TQM dapat diartikan suatu komitmen budaya organisasi untuk memuaskan custamer lewat pengunaan struktur terintegrasi dari peralatan, teknik, dan pelatihan. TQM mencakup perbaikan terus menerus proses organisasi, dengan hasil peroduk dan jasa bermutu tinggi. Manajemen mutu terpadu dapat diterapkan dalam bidang kependidikan sebagaimana yang Sallis (1997:24) nyatakan: 
"Quality derived from business experience is applicable to education, but that it requires a degree of adaptation to fit both the general educational setting and the particular circumstances of each school, collage or university". Manajemen mutu terpadu diperlukan untuk memecahkan masalah masalah pendidikan yang krusial dalam upaya meningkatkan kemampuan (competences) bagi pembangunan.

Kaitannya dengan proses layanan di perguruan tinggi, bahwa manajemen untuk mencapai kualitas pada Perguruan Tinggi adalah suatu pendekatan yang sifatnya tidak langsung, namun melalui berbagai aspek yang sifatnya multidimensional. Artinya dipengaruhi oleh penekanan tentang keterlibatan individu profesional dan unit terkait yang memberikan rangsangan (stimulating). Untuk koordinasi diantara semua dimensi perlu diupayakan sehingga menjadi suatu mekanisme kesejawatan dalam rancangan program akademis dan pengendalian kualitas. Mekanisme kesejawatan ini sesungguhnya menunjuk pada kualitas orang (manusianya). Dalam bahasa lain, yang menjadi kunci dalam kualitas, terutama manusianya, bukan terletak pada proses dan mekanisme. Manusia kerja ini dipersyaratkan untuk meraih Zero Defect atau bekerja sesempurna mungkin (Stoner, 1992). Walaupun demikian sistem operasional tetap harus dirancang sebaik mungkin.

Berbeda dengan manajemen industri, fokus Total Quality Manajement (TQM) dalam mencapai manajemen kualitas di Perguruan Tinggi (management for quality in higer education institutions) pada dua hal, yaitu: Pertama, Stimulasi dari koherensi proses belajar, sehingga tidak terjadi disintegrasi kurikulum. Hal ini mudah dipahami mengingat setiap rancangan dan proses perencanaan kurikulum termasuk implmentasinya melibatkan berbagai aktor yang heterogen baik gaya, latar belakang, serta tingkat profesionalitasnya.

Heterogenitas aktor ini memungkinkan terjadinya fragmentasi dalam inplementasi kurikulum. Padahal dalam manajemen mencapai kualitas di lembaga pendidikan tinggi harus diupayakan integrasi kurikulum, dan disintegrasi kurikulum harus dicegah dengan cara menciptakan koherensi proses belajar mengajar. Tugas ini menuntut stimulasi pola 
dan unsur yang konsisten dan terinterelasikan.

Kedua, Analisis kebutuhan berbagai kelompok peserta didik. Mahasiswa sebagai peserta didik, perlu perhatikan khusus, karena mereka sesungguhnya adalah aktor dimasa depan baik sebagai guru, manajer perushaan, birokarat atau teknokrat serta pelaku profesi lainnya. Oleh karenanya orientasi terhadap peserta didik adalah kunci management for quality in higer education institutions.

Dalam pemikiran Romizowzky yang dikutip Conny Semiawan (1999), mengungkapkan bahwa manajemen kualitas total di perguruan tinggi setidak-tidaknya menuntut adanya analisis dua jalur yang disebut two road analysis (frond-end), yang mencakup tiga komponen yaitu, (1) siapa mahasiswa yang kita hadapai (traget group analysis), apa sasaran program kita (content analyis), serta relevansi program dengan kebutuhan ujung dari program tersebut (context analysis). Dalam bahasa lain kompetensi apa yang perlu diberikan untuk memiliki kemampuan sesuai dengan tuntutan pekerjaan (front), sehingga peserta didik (mahasiswa) memiliki kompetensi yang diperlukan pada ujung program tersebut (end) untuk menjalankan pekerjaan tertentu (job analysis).

Dengan demikian pendidikan tinggi bukanlah semata-mata soal psycal product, seperti pada bidang industri atau pabrik, karena raw input perguruan tinggi adalah manusia dan hasil pendidikan (out put) adalah manusia yang akan teruji kemampuannya pada saat individu itu berinteraksi dengan mansuia lain dalam hidup dan kehidupan. Mutu hasil pendidikan formal sangat dipengaruhi oleh mutu input dan mutu proses pembelajarnnya. Oleh karena itu, seluruh komponen dalam sistem perguruan tinggi diarahkan secara terpadu untuk mendukung tercipatanya proses transpormasi nilai yang sebaik-baiknya. Dengan kata lain, hasil belajar tidak hanya sekedar mengetahui dan memahami, melainkan harus bisa mencapai kemampuan berpikir tingkat tinggi (higer oreder thinking skills). Menurut Engkoswara (1987) sebagaimana dikutif oleh (Tjutju Yuniarsih, 2003:11) higer order thinking skills ditandai oleh 
adanya kemampuan untuk berpikir kritis, analitis kreatif, reflektif, dan transformational.

\section{PENUTUP}

Sebagai kata akhir dari uraian di atas, dapat disimpulkan bahwa problematika yang dihadapi dunia pendidikan khususnya pendidikan tinggi di Indonesia, yang diindikasikan dengan rendahnya pemerataan dalam memperoleh pendidikan, lemahnya manajemen pendidikan, serta rendahnya kualitas dan relevansi pendidikan, merupakan potret rendahnya mutu pendidikan tinggi di Indonesia, sehingga perlu secara serius dicarikan stategi peningkatannya. Untuk itu tidak terlalu berlebihan apabila dunia pendidikan dalam upaya meningkatkan mutunya tersebut, mencoba menerapkan konsep baru dari bidang lain seperti halnya dunia bisnis yang selama ini menerapkan manajemen mutu terpadu atau Total Quality Management (TQM).

Tentu saja untuk menerapkan konsep tersebut tidak terlalu mudah, sehingga perlu keseriusan semua pihak baik para pengambil kebijakan dalam menetapkan regulasi pendidikan nasional, maupun pihak penyelenggara dan pengelola pendidikan dalam bentuk layanan mutu kepada masyarakat pengguna jasa pendidikan, serta pihak lain yang tak kalah pentingnya yakni dunia usaha dalam menentukan keberpihakannya bagi dunia pendidikan sebagai implementasi partisifasinya dalam meningkatkan mutu pendidikan tinggi di negeri tercinta ini.

\section{DAFTAR PUSTAKA}

Asep Saepudin. 2003. Pendekatan Total Quality Manajemen (TQM) dalam Globalisasi Pendidikan. Jurnal Manajemen dan Sistem Informasi. Bandung. FPIPS UPI Vol. 1 No.2 Januari 2003. 2001. Potret Pendidikan dalam Alih IImu dan Teknologi. Jurnal Teknodik. Pustekom Depdiknas No.9 Januari 2001. Asia Week. 2000. Best Multi-Disiplinary institutions and Institutes of Science and Technology (On-Line). 
http://www.cnn.com/ASIANOW/asiaweek/universities. (15 September 2000).

Azrul Azwar. 1995. Program Menjaga Mutu Pelayanan. Jakarta: Yayasan penerbit IDI.

Bun Yamin Ramto. 2000. Strategi Pengembangan Perguruan Tinggi Swasta di Indonesia. APTISI Jawa Barat.

Conny R. Semiawan. 1999. Pendidikan Tinggi: Peningkatan Kemampuan Manusia. Jakarta; PT. Grasindo.

Domingo, Rene T 1992. "Non Stop Improvement: Quality Redefined". The Asean Manager. July-August 1992.

Direktori Akreditasi Program Studi tahun 2003. Jakarta: BAN PT.

Elaine Biech, 1994. Total Quality Management for Training. New York. McGraw-Hill, Inc.

Joetata Hadihardaja. 2000. Kebijakan Pemerintah Mengenai Perguruan Tinggi. Kopertis Wil. IV

M.D. Dahlan. 2000. Implikasi Otonomi Perguruan Tinggi bagi Pengembangan PTS. Bandung. Makalah APTISI Jabar.

Murato, Eduardo. 1993. "The Essence of Quality: Two Essays". The Asian Manager. January 1993.

Sallis, Edward. 1993. Total Quality Management in Education. Kogan Page Educational Management Series. Philadelphia. London.

Safrudin Chamidi. 2004. Kontribusi Sekolah Swasta bagi Pendidikan di Indonesia. (On Line) http://www.depdiknas.go.id/Jurnal/35/ kontribusi_sekolah_swasta.htm (27 Juni 2004)

Tampubolon, Daulat. 2001. Perguruan Tinggi Bermutu. Jakarta: Gramedia Pustaka Utama.

Tjutju Yuniarsih. 2003. Implementasi Konsep Mutu Terpadu dalam Pendidikan. Jurnal Manajemen dan Sistem Informasi. Bandung. FPIPS UPI Vol. 1 No.2 Januari 2003. 